
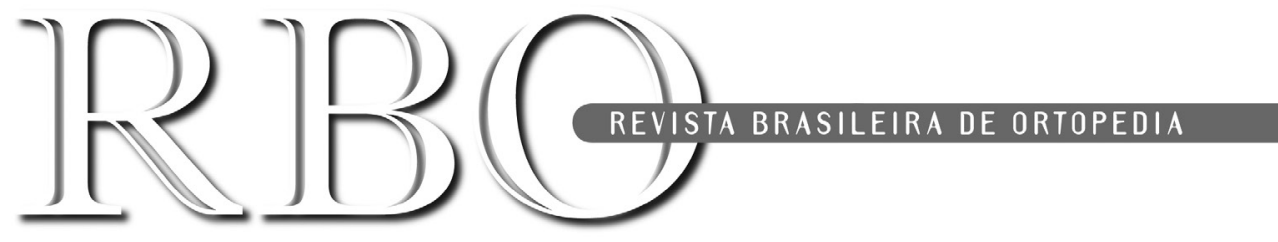

\title{
Editorial
}

\section{A história de um suplemento}

Desde a origem da ideia, a organização, a comunicação aos associados, o recebimento dos artigos, a correção, a editoração, os custos, a impressão dos exemplares, o envio pelo correio e a leitura pelos membros da Sociedade Brasileira de Ortopedia e Traumatologia (SBOT), com certeza muita água passou por debaixo da ponte. Páginas e páginas poderiam ser escritas abordando essa experiência, por vezes não muito aprazível, mas ao final muito gratificante.

Agradecemos a todos os autores, ao Gilberto Luis Camanho, ao Osvandré Lech, à Diva Godoi e, em especial, ao Willian Dias Belangero pela realização de mais essa edição do Suplemento de Ortopedia Pediátrica.

A Ortopedia Pediátrica brasileira está bem representada nos artigos apresentados.

A necessidade da divulgação de conhecimentos, objetivo maior da nossa missão na Sociedade Brasileira de Ortopedia Pediátrica (SBOP), foi bem compreendida pelo editor-chefe da Revista Brasileira de Ortopedia (RBO) e pelo presidente da SBOT.

Com a edição de mais esse suplemento, a RBO cumpre o seu papel indispensável na difusão da produção científica nacional.

Neste número dedicado à Ortopedia Pediátrica, encontramos assuntos diversos que bem demonstram a enorme abrangência dos temas que envolvem as crianças e os adolescentes.

A Diretoria da SBOP sente-se orgulhosa do grande conhecimento científico dos seus associados, matéria que fica aqui patente pela qualidade dos trabalhos enviados.

Esperamos continuar contando com a colaboração de todos para as próximas edições.

Boa leitura! 